\title{
A study of relationship of hyperuricemia in hypothyroid patients
}

\author{
Jat A. ${ }^{\mathbf{1}}$, Khare A. ${ }^{2 *}$, Patel N. ${ }^{3}$ \\ DOI: https://doi.org/10.17511/ijmrr.2019.i01.04 \\ 1 Anand Jat, Assistant Professor, Department of General Medicine, L.N. Medical College and Research Centre, Bhopal, Madhya Pradesh, \\ India. \\ 2* Apurva Khare, Associate Professor, Department of General Medicine, L.N. Medical College and Research Centre, Bhopal, Madhya Pradesh, \\ India. \\ ${ }^{3}$ Narmada Patel, Professor, Department of General Medicine, L.N. Medical College and Research Centre, Bhopal, Madhya Pradesh, India.
}

Introduction: Hypothyroidism is a common metabolic disorder in general population. The prevalence of primary hypothyroidism is $1: 100$, but it may be $5: 100$ if patients with subclinical hypothyroidism (normal T4, raised TSH) are included. The degree of severity ranges from mild and unrecognized hypothyroid states to striking myxedema. The thyroid dysfunction increases with age, especially in women Uric acid has been found to be significantly elevated in primary hypothyroidism in many studies. In comparison to the prevalence reported in the general population, a significant increase of both Hyperuricemia and gout was found in the hypothyroid patients. In hypothyroidism, the hyperuricemia is secondary to a decreased renal plasma flow and impaired glomerular filtration This study was designed for evaluation of uric acid levels in hypothyroid patients which might be helpful for clinical management of hypothyroid patients with hyperuricemia. Objective of Study: To find out any relationship between hyperuricemia in hypothyroidism patients. Methods: In our study, out of 100 patients, only 15 were found to have increased serum uric acid levels and only 3 had increased urinary uric acid levels. Out of these 15, 9 were females and 6 males, or can be said out of 70 females in study; only 9 were having increased serum uric acid levels. Results: In our study, the association between hypothyroid function and hyperuricemia seems to be week. No significant correlation was found betweenT3, T4 \& TSH and serum uric acid. Conclusion: The correlation between hypothyroidism and gout still remains a matter of debate and more extensive studies need to be done to come to a definitive conclusion.

Keywords: Hypothyroidism, Uric Aric, Hyperuricemia

\section{Corresponding Author}

Apurva Khare, Associate Professor, Department of General Medicine, L.N. Medical College and Research Centre, Bhopal, Madhya Pradesh, India. Email: drapurvakhare@rediffmail.com
How to Cite this Article

To Browse

Jat A, Khare A, Patel N. A study of relationship of hyperuricemia in hypothyroid patients. Int J Med Res Rev. 2019;7(1):19-23.

Available From

https://ijmrr.medresearch.in/index.php/ijmrr/article/ view/1030

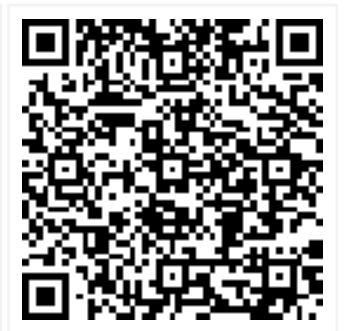

\begin{tabular}{|c|c|c|c|c|}
\hline \multirow{2}{*}{\multicolumn{2}{|c|}{$\begin{array}{c}\text { Manuscript Received } \\
2019-01-14 \\
\text { Conflict of Interest } \\
\text { No }\end{array}$}} & $\begin{array}{c}\text { Review Round } 1 \\
2019-01-24\end{array}$ & $\begin{array}{c}\text { Review Round } 2 \\
2019-01-31\end{array}$ & Review Round 3 \\
\hline & & $\begin{array}{c}\text { Funding } \\
\mathrm{Nil}\end{array}$ & $\begin{array}{c}\text { Ethical Approval } \\
\text { Yes }\end{array}$ & $\begin{array}{c}\text { Plagiarism X-checker } \\
5 \%\end{array}$ \\
\hline OPEN & \multicolumn{4}{|c|}{$\begin{array}{l}\text { (c) } 2019 \text { by Anand Jat, Apurva Khare, Narmada Patel and Published by Siddharth Health Research and Social Welfare Society. } \\
\text { This is an Open Access article licensed under a Creative Commons Attribution } 4.0 \text { International License } \\
\text { https://creativecommons.org/licenses/by/4.0/ unported [CC BY 4.0]. }\end{array}$} \\
\hline
\end{tabular}




\section{Introduction}

The thyroid gland produces two related hormones, thyroxine (T4) and triiodothyronine (T3) Acting through thyroid hormone receptors, these hormones play a critical role in cell differentiation during development and help maintain thermogenic and metabolic homeostasis in the adult. Autoimmune disorders of the thyroid gland can stimulate overproduction of thyroid hormones (thyrotoxicosis) or cause glandular destruction and hormone deficiency (hypothyroidism).

Hypothyroidism is a clinical syndrome resulting from a deficiency of thyroid hormones which, in turn, results in a generalized slowing down of metabolic processes. Hypothyroidism affects over $1 \%$ of the general population and about $5 \%$ of individuals over age 60 years [1]. It was pointed out in many studies that there exist a relationship between Hypothyroidism and Hyperuricemia which can contribute to increased number of complications in these patients [2]. This study was intended to study this correlation.

\section{Methodology}

Study of population: Patients with Hypothyroidism (Subclinical and Clinical) attending opd/ipd in L.N Medical College and J.K Hospital, Bhopal, MP, India

Ethical Considerations and Permissions obtained from Ethical Body of L.N Medical College and Research Centre, Bhopal, MP, India

Study design: cross sectional study.

Sample size: 100 patients.

Duration of study: nov. 2017 to oct. 2018

We plan to take cases of hypothyroidism and check their serum uric acid levels at presentation.

Both new and previously diagnosed case of hypothyroidism. After taking informed consent from each of the volunteer, $3 \mathrm{ml}$ blood was drawn and levels of serum T3,T4,TSH and uric acid level and $5 \mathrm{ml}$ of urine samplewere estimatedby same method and same lab for each same. Random blood samples were drawn as and when the volunteer came.

\section{Study tools}

01. Serum T3, T4 \& TSH result.

02. Serum uric acid result.

03. Urine uric acid result.
Surgical Procedure: No Surgical procedure was involved in above study.

Statistical tools used: Pearson's correlation coefficient

\section{Inclusion criteria}

01. Patients with hypothyroidism (known case, newly diagnosed \& subclinical).

02. Aged between 13 - 45 years.

03. Patients who are already on treatment for hypothyroidism

\section{Exclusion criteria}

01 . Age $<13$ and $>45$ will be excluded.

02. Alcoholic patients.

Who refuse to give consent

\section{Result}

Table-1: Age wise distribution of the patients.

\begin{tabular}{|l|l|l|}
\hline \multicolumn{1}{|c|}{ Age } & \multicolumn{1}{c|}{ No of patients } & \multicolumn{1}{c|}{ Percent (\%) } \\
\hline 20 less & 4 & 4.0 \\
\hline $20-29$ & 36 & 36.0 \\
\hline $30-39$ & 37 & 37.0 \\
\hline $40-49$ & 23 & 23.0 \\
\hline Total & 100 & 100.0 \\
\hline
\end{tabular}

Age-There were only 4 patients less than 20 years of age and 23 patients between 40-49 years of age and 36 patients between 20-29 years of age while $\max$.

Table-2: Sex wise distribution of the patients

\begin{tabular}{|l|l|l|}
\hline \multicolumn{1}{|c|}{ Sex } & \multicolumn{1}{c|}{ No of patients } & \multicolumn{1}{c|}{ Percent (\%) } \\
\hline Female & 70 & 70.0 \\
\hline Male & 30 & 30.0 \\
\hline Total & 100 & 100.0 \\
\hline
\end{tabular}

Table-3: Types of hypothyroid cases with classification and serum uric acid levels with its mean values

\begin{tabular}{|c|c|c|c|c|c|}
\hline \multirow[t]{2}{*}{$\begin{array}{l}\text { Hypothyroid } \\
\text { cases }\end{array}$} & \multicolumn{2}{|c|}{$\begin{array}{c}\text { serum uric acid } \\
(3-7 \mathrm{mg} / \mathrm{dl})\end{array}$} & \multirow[t]{2}{*}{$\begin{array}{l}\text { Mean serum } \\
\text { uric acid level }\end{array}$} & \multirow{2}{*}{$\begin{array}{c}\text { Std. } \\
\text { Deviation }\end{array}$} & \multirow{2}{*}{$\begin{array}{c}\text { Total } \\
\text { Percentage } \\
(\%)\end{array}$} \\
\hline & $>7$ & $<7$ & & & \\
\hline $\begin{array}{l}\text { Newly } \\
\text { diagnosed }\end{array}$ & 7 & 29 & 6.25 & 1.08 & 36 \\
\hline Subclinical & 1 & 16 & 5.65 & 1.32 & 17 \\
\hline Known Case & 7 & 40 & 6.30 & 1.20 & 47 \\
\hline Total & 15 & 85 & 6.17 & 1.19 & 100 \\
\hline
\end{tabular}

Sex distribution: Out of 100 patients there were 70 female and 30 males. 
Out of the 15 cases in which serum uric acid level were above $7 \mathrm{mg} / \mathrm{dl}, 9$ are female hypothyroid patients and 6 are male hypothyroid patients.

Out of the hypothyroid cases, 36 were newly diagnosed and 17 were subclinical. Rest of the 47 cases were known hypothyroid cases. Of these, only 15 cases had increased serum uric acid levels.

Table-4: Types of hypothyroid cases with classification and urine uric acid levels with its mean values.

\begin{tabular}{|c|c|c|c|c|c|}
\hline \multirow[t]{2}{*}{ Total } & \multicolumn{2}{|c|}{$\mid \begin{array}{c}\text { urine uric acid (300- } \\
800 \mathrm{mg} / 24 \mathrm{hrs})\end{array}$} & \multirow[t]{2}{*}{$\begin{array}{l}\text { Mean urine } \\
\text { uric acid level }\end{array}$} & \multirow[t]{2}{*}{$\begin{array}{c}\text { Std. } \\
\text { Deviation }\end{array}$} & \multirow[t]{2}{*}{$\begin{array}{l}\text { Number of } \\
\text { patients }\end{array}$} \\
\hline & $>800$ & $<800$ & & & \\
\hline $\begin{array}{l}\text { Newly } \\
\text { diagnose } \\
\text { d }\end{array}$ & 1 & 35 & 431.89 & 168.07 & 36 \\
\hline \begin{tabular}{|l|} 
Subclinic \\
al
\end{tabular} & 0 & 17 & 504.12 & 118.32 & 17 \\
\hline Known & 2 & 45 & 423.19 & 216.13 & 47 \\
\hline Total & 3 & 97 & 440.08 & 186.60 & 100 \\
\hline
\end{tabular}

Out of the 100 cases included in the study, only 3 were found to have raised urine uric acid levels.

Table-5: Correlation of TSH level and serum Uric Acid Level

\begin{tabular}{|l|l|l|l|}
\hline \multirow{2}{*}{ TSH } & \multicolumn{2}{|c|}{ serum uric acid (3-7 mg/dI) } & \multirow{2}{*}{ Total } \\
\cline { 2 - 4 } & $>7$ & $<7$ & \\
\hline$>5.5$ & 12 & 64 & 76 \\
\hline$<5.5$ & 3 & 21 & 24 \\
\hline Total & 15 & 85 & 100 \\
\hline
\end{tabular}

When correlated with serum TSH levels, serum uric acid of $>7$ were found in 15 patients in which TSH levels of $>5.5$ was seen in 12 patients.

Table-6: Correlation of T3 level and serum uric acid level

\begin{tabular}{|l|l|l|l|}
\hline \multirow{2}{*}{ T3 level } & \multicolumn{2}{|c|}{ serum uric acid $(3-7 \mathrm{mg} / \mathrm{dI})$} & \multirow{2}{*}{ Total } \\
\cline { 2 - 4 } & $>7$ & $<7$ & \\
\hline 9 & 6 & 30 & 36 \\
\hline$>9$ & 9 & 55 & 64 \\
\hline Total & 15 & 85 & 100 \\
\hline
\end{tabular}

When correlated with serum T3 levels, serum uric acid of $>7$ were found in 15 patients in which T3levels of $<9$ was seen in 6 patients.

Table-7: Correlation of $\mathbf{T}$ Level and Serum Uric Acid Level

\begin{tabular}{|l|l|l|l|}
\hline \multirow{2}{*}{ T4 level } & \multicolumn{2}{|c|}{ serum uric acid $(3-7 \mathrm{mg} / \mathrm{dl})$} & \multirow{2}{*}{ Total } \\
\cline { 2 - 4 } & $>7$ & $<7$ & \\
\hline$<3.5$ & 8 & 14 & 22 \\
\hline
\end{tabular}

\begin{tabular}{|l|l|l|l|}
\hline$>3.5$ & 7 & 71 & 78 \\
\hline Total & 15 & 85 & 100 \\
\hline
\end{tabular}

When correlated with T4 levels. Serum uric acid of $>7$ were found in 15 patients in which T4 level of $<3.5$ was seen in 8 patients.

In our study, the association between hypothyroid function and hyperuricemia seems to be week, both in known as well as newly detected hypothyroid patients with only one out of all the variables tested turned out to have significant correlation.

01 . TSH and serum uric acid $(p=0.62)$

02. T3 and serum uric acid $(p=0.73)$

03. TSH and urine uric acid $(p=0.71)$

04. T3 and urine uric acid $(p=0.93)$

05. T4 and urine uric acid $(p=0.35)$

06. Significant correlation between T4 and serum uric acid $(P=0.001)$

The naming of the thyroid gland (Greek thyreos, shield, pluseidos, form) has been attributed to Wharton in 1656, but an endocrine function was not proposed until almost 200 years later [3]. Hypothyroidism is a common endocrine disorder resulting from deficiency of thyroid hormone. It is often the primary process in which the thyroid gland produces in sufficient amounts of thyroid hormone. It can also be secondary, i.e., lack of thyroid hormone secretion due to the failure of either adequate thyrotropin (TSH) secretion from the pituitary gland or thyrotropin-releasing hormone (TRH) from the hypothalamus (secondary or tertiary hypothyroidism).

The patient's presentation may vary from asymptomatic to, rarely, coma with multisystem organ failure (myxoedema coma). The Whickham survey specifically sought to determine the incidence of thyroid disease in the general population [4].

Worldwide, iodine deficiency remains the foremost cause of hypothyroidism. In the areas of adequate iodine intake, autoimmune thyroid disease (Hashimoto's thyroiditis) seems to be the most common cause. Hashimoto's thyroiditis is part of the spectrum of autoimmune thyroid diseases.

\section{Causes of Hypothyroidism}

Treatment- The treatment goals for hypothyroidism are the reversal of clinical progression and the corrections of metabolic derangements. 
Thyroid hormone is administered to supplement or replace endogenous production. In general, hypothyroidism can be adequately treated with a constant daily dose of levothyroxine. Clinical benefits begin in 3-5 days and level off after 4-6 weeks.

Anticipated full replacement doses may be initiated in individuals who are otherwise young and healthy. In elderly patients or those with known ischaemic heart disease, treatment should begin with one fourth to one half the expected dose, and the dose should be adjusted in small increments no sooner than 4-6 weeks [5].

The correct dose is that which restores the euthyroid state and relieves symptoms. In most patients these will be achieved by a dose of thyroxine resulting in a normal or slightly raised serum thyroxine concentration, a normal serum triiodothyronine concentration, and a normal or below normal serum thyroid stimulating hormone concentration [6]. T4 monotherapy remains the treatment of choice $[7,8]$. Giordano $N$ et alin their

Study evaluated the prevalence of hyperuricemia and gout in patients affected by primary hypothyroidism and hyperthyroidism. They studied 28 patients with primary hypothyroidism and 18 patients with primary hyperthyroidism, all hospitalized because of endocrine dysfunction [8].

They observe that in comparison to the prevalence reported in the general population, a significant increase of both hyperuricemia and gout was found in the hypothyroid patients, and of hyperuricemia in the hyperthyroid patients. In hyperthyroidism the hyperuricemia is due to the increased urate production, while in hypothyroidism the hyperuricemia is secondary to a decreased renal plasma flow and impaired glomerular filtration.

Past studies have reported an association between hyperuricemia and thyroid disorders with conflicting results. The correlation between TSH and serum uric acid levels was found to be weak in the study by Saini $V$ et al [9], which is consistent with our findings.

Despite evidence suggesting links between thyroid function and hyperuricemia [10], it seems that renal function is a stronger factor for determining serum uric acid levels [11] and therefore the association between hypothyroid status and hyperuricemia is not significant if renal function is not a part of the model.

\section{Conclusion}

Our study evaluated the possible inter-relationship between purine nucleotide metabolism and thyroid endocrine disorders, in particular primary hypothyroidism, by examining the data in the literature and comparing this with the data observed in a case study. In the literature, the correlation between hypothyroidism and hyperuricemia is still not clear. The present study investigated the risk of hyperuricemia associated with thyroid dysfunction in 100 people. The correlation between TSH and serum uric acid levels was not found to be significant $(p=0.62)$.

However, a statistically significant correlation ship was found between $\mathrm{T} 4$ and serum uric acid $(p=0.001)$. Hypothyroid status was not found to be significantly associated with hyperuricemia. This study suggests that hypothyroidism does not have any role in disruption of uric acid metabolism. But few studies showed increased serum uric acid with hypothyroidism. The uncertainty of association between hypothyroidism and uric acid metabolism still prevails. Finally to conclude, the correlation between hypothyroidism and gout still remains a matter of debate and more extensive studies need to be done to come to a definitive conclusion.

\section{Contribution by authors}

Sample collection and data analysis was done by Anand Jat (1st author), compilation of data and stastical analysis done by Apurva Khare and Narmada Patel (corresponding author and 3rd author).

\section{Learning from the present study}

As there is paucity of Indian studies on this topic, there was certainly a possibility of correlation between Hypothyroidism and Hyperuricemia atleast in Indian patients.

But our results didn't find any correlation except a significant correlation between serumT4 levels and hyperuricemia, which encourages us to further explore this possibility.

\section{Limitations of Study}

01. Evaluation of renal functions should have been done.

02. Sample size should have been bigger. 


\section{Reference}

01. Mark P, J Vanderpump. Epidemiology of Thyroid Disease. British Medical Bulliten. 2011;99;3951.

DOI $10.1093 / \mathrm{bmb} /$ idr030 [Crossref]

02. Gagandeep Kaur Sidhu, Rahima R Malek, Asha Khubchandani, Sohil H Mansuri, Miku S Patel, Ruhan H Oza. A Study of Serum Urea, Creatinine and Uric Acid Levels in Hypothyroid Patients. Int J Res Med. 2016;5(2)115-118. [Crossref]

03. Ueda $H$, Howson JM, Esposito $L$, et al. Association of the T-cell regulatory gene CTLA4 with susceptibility to autoimmune disease. Nature. 2003 May 29;423(6939)506-11.

DOI: $10.1038 /$ nature01621 [Crossref]

04. Britto JM, Fenton AJ, Holloway WR, et al. Osteoblasts mediate thyroid hormone stimulation of osteoclastic bone resorption. Endocrinology. 1994 Jan;134(1)169-76.

DOI: $\quad 10.1210 /$ endo.134.1.8275930 [Crossref]

05. Surks MI. Response to position statement on subclinical thyroid dysfunction. Endocr Pract. 2004 Nov-Dec;10(6)513-4.

DOI: $10.4158 /$ EP.10.6.513 [Crossref]

06. Fatourechi V, Klee GG, Grebe SK, et al. Effects of reducing the upper limit of normal TSH values. JAMA. 2003 Dec 24;290(24)3195-6.

DOI: $\quad 10.1001 /$ jama.290.24.3195-b [Crossref]

07. Hamilton TE, et al. Thyrotropin levels in a population with no clinical, autoantibody, or ultrasonographic evidence of thyroid diseaseimplications for the diagnosis of subclinical hypothyroidism. J Clin Endocrinol Metab. 2008 Apr;93(4)1224-30.

doi: $10.1210 /$ jc.2006-2300 [Crossref]

08. Giordano N, Santacroce C, Mattii G, et al. Hyper-uricemia and gout in thyroid endocrine disorders. Clin Exp Rheumatol. 2001 NovDec;19(6)661-5.

[Crossref]
09. Saini V, Yadav A, Arora MK, et al. Correlation of creatinine with TSH levels in overt hypothyroidism- a requirement for monitoring of renal function in hypothyroid patients?. Clin Biochem. 2012 Feb;45(3)212-4.

doi: $10.1016 /$ j.clinbiochem.2011.10.012 [Crossref]

10. Domrongkitchaiporn S, Sritara P, Kitiyakara C, et al. Risk factors for development of decreased kidney function in a southeast Asian populationa 12-year cohort study. J Am Soc Nephrol. 2005 Mar;16(3)791-9. DOI:10.1681/ASN.2004030208 [Crossref]

11. Johnson GC, Esposito L, Barratt BJ, et al. Haplotype tagging for the identification of common disease genes. Nat Genet. 2001 Oct;29(2)233-7.

[Crossref] 